\title{
A CASE OF CHONDROSARCOMA IN IRRADIATED MANDIBLE
}

\author{
YUICHI SHIRAHATA, M.D. AND YOSHIO HONDA, M.D. \\ Department of Otolaryngology, the Jikei University School of Medicine, Tokyo
}

(Director: Prof. Y. Honda, M. D.)

\begin{abstract}
A review was made of clinical aspects of osteogenic sarcoma, particularly of chondrosarcoma induced by external irradiation and an additional case was reported.

A 14-year-old female developed chondrosarcoma in the mandible 4 and a half years after deep X-ray therapy for malignant lymphoma of the maxilla. Discussions were made on the nature of chondrosarcoma in the facial region, ubiqutious tumor of osseous orgin, and on the role of irradiation in the development of malignant tumor of the bone.
\end{abstract}

A $80-0497-91307$

\section{放射線照射後に生じた顎軟骨肉腫の 1 例}

\author{
東京意惠会医科大学耳䁷哂喉科学教室（主任：本田芳男教授）
}

$$
\text { 白幡雄一本多芳男 }
$$

\section{I 緒 言}

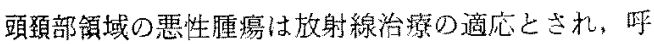
吸，掑取，発育などの機能そ保持しらる点からもそれは 極めて有利な治療法である、高代エネルギー発生装置の

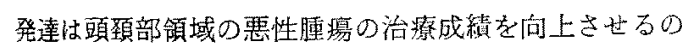
飞役立ったが，反面，病巣線量增加に伴万澡在性の同所 障害は常に問題である。隹来，皮融ならびにその付属器 宫に対する障㫮が局所障害の大部分であったが，最近は

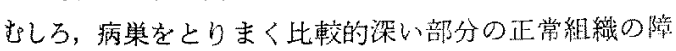

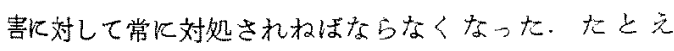
は，胸部照射による肺組織の障害は最近特に強熘される ところであるが，耳鼻咽喉科領域でも古くから上钼癌照

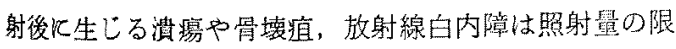
界をとこに拓くべきかという問題と関連して諭じられて

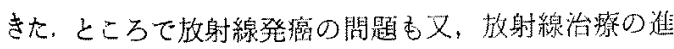
歩と表裹一体の関係をもつ放射線障害としてとりあげら れねばならない，放射線は癌を治し，かつまたその原因 ともなり得るが，支の場合即座に癌の原因となるのでは なく普通怙何年かの潜伏期の後に机こる。このように，

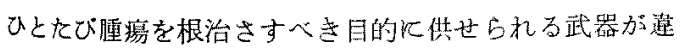

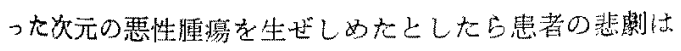
培增し，患者は運命の過酷されらちひしが机ることであ ろち.
われわれはまさにそのような例化合致する postradiation bone sarcoma 015 藏の女子の一例花最近経娩し

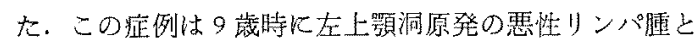
衫䉼さ机，リニヤック照射を受け，その娞 5 年間再発な く経過したが，その同じ照射部に含まれる下顎骨に瑱骨

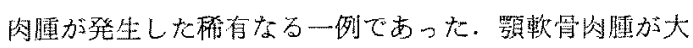
変珍しい上飞その病因加既存の放射線治療氏あると思わ れた興味ある症例である。そこて，症例の臨床的に観繁 した概要をここに報告するとともに，放射線悪性蕾演と 頑軟骨肉雨の闬方に文献的考察を加えてみた。諸賢の御 批判を仰げ九ば萃いである。

$$
\begin{aligned}
& \text { II 症例 } \\
& \text { 患 者: } 14 \text { 藏女性（第 } 1 \text { 回初診時 } 9 \text { 藏） } \\
& \text { 初㟝：筆1回昭和46年6月10日 } \\
& \text { 籍2回 昭和51年2月16日 }
\end{aligned}
$$

家族歴：特記すへきことなし

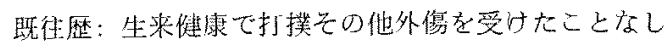
A) 第 1 回初觖の病歴

主訴：在頓部腫脤

現病歴㕲よび経過:

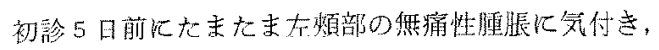

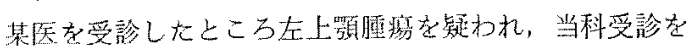

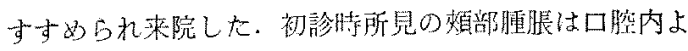




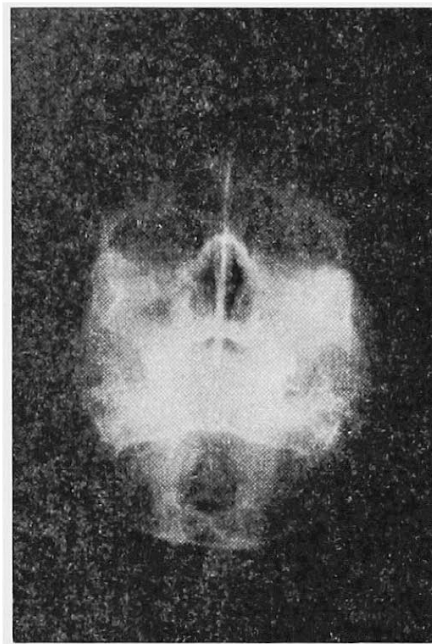

第 1 回初診 時

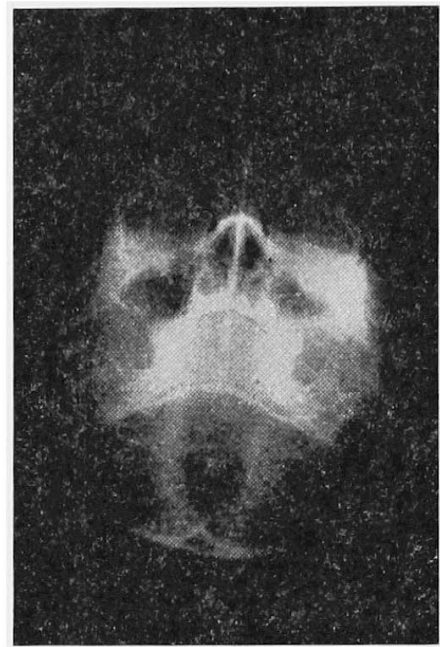

初回治療終了時

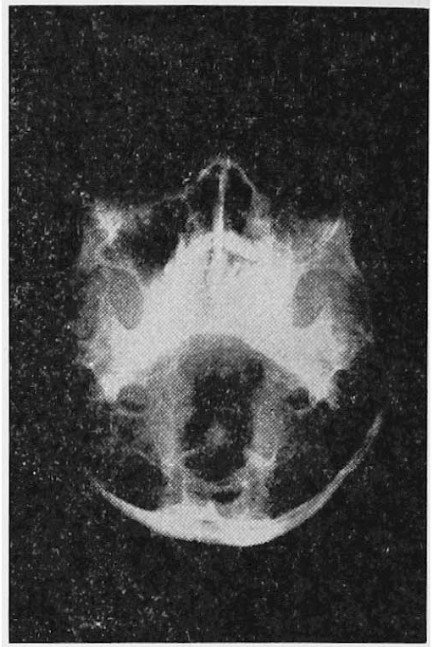

第 2 回 初診 時

図 1 Waters レ線での比較

り触診すると, 左上㖽歯槽突起より硬口蓋にかけて硬く 表面平滑, 非可動性, 辺縁不明瞭, 鴊卵大の膨隆として 認められた，頚部リンパ節は腫脹を認めない，鼻腔はほ ほ正常・胸部はレントゲン所見を含めて特記すべき所見 はない，耳咽頭も正常である，全身所見でも著变なし， 副鼻腔単純 X線検査では左上顎洞は強度混濁し上顎洞の 後壁飞骨欠損が認められる，右上顎洞にも柽度の肥厚が あり副鼻腔炎の存在が考えられた（図 1)．この単純レ線 撮影で認められた左上顎洞の变化を断層像で追跡すると 上䫇洞の前壁，下壁，外側壁，後壁の一部が破壊されて いた. そこで 7 月 1 日入院させ， 7 月 6 日左上須洞試験 開洞を行なったが，その結果上顎洞前壁の骨破壊が認め られ，骨欠損をと扮して白く光沢ある充実性，柔軟な腿 瘍が煩部結合織へ突出していて上顎洞は腫瘍で充満され ていた.この腫瘍の突出部にその中央で縦切開を入れ， 分厚い弾性硬の腫瘍の一部を採取した。そ組織診断の 結果は悪性リンパ腫と判明した.

組織学的所見

図 2 では多形性, 異形性なる大型の細胞の膄瘍性增殖 をみる、これらの細胞の中心部にはところどころに大き な核小体があり，核は概して棈円型又はくびれのある不 整球状を呈している．またよく見ると胞体は多角形で觉 起による細胞間の連絡があるようにも思える．各細胞間 には小型円形な成熟リンパ球が点在し血管外膜細胞の増 生がある。この組織所見からすると hystiocytic な細胞 が腫瘍細胞の主体をなしていることより Rapaportの言

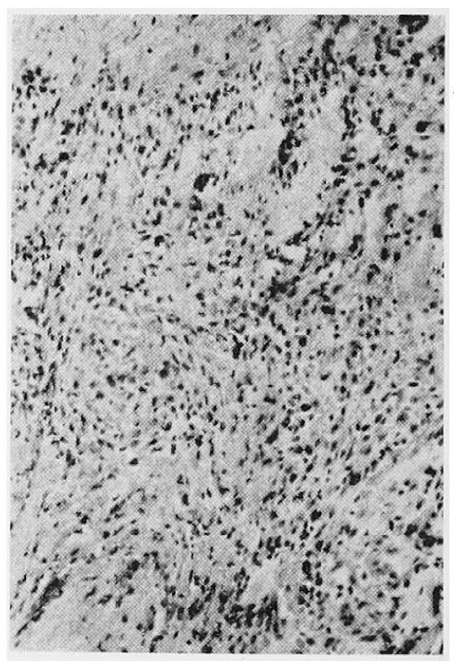

図 2

ういわゆる hystiocytic type malignant lymphoma が 考えられる。

以上の結果より直らにリニャック照射を開始した。 （2月9日より8月12日までの 34 日間, 楔状フィルター を用いた直角 2 方向外部照射で総線量 $5000 \mathrm{rad}$ )（図 3) 照射と平行して7月16日より8月14日までエンドキサン 総量 $2500 \mathrm{mg}$ ，プレドニン総量 $600 \mathrm{mg}$ を投与した．以 上の治療により腫陽の縮小が著しく認められたので，患 者は 8 月 21 日退院した. 以来 4 年間全く再発の傾向はみ られず経過は良好であった。しかし，昭和 51 年 2 月初 


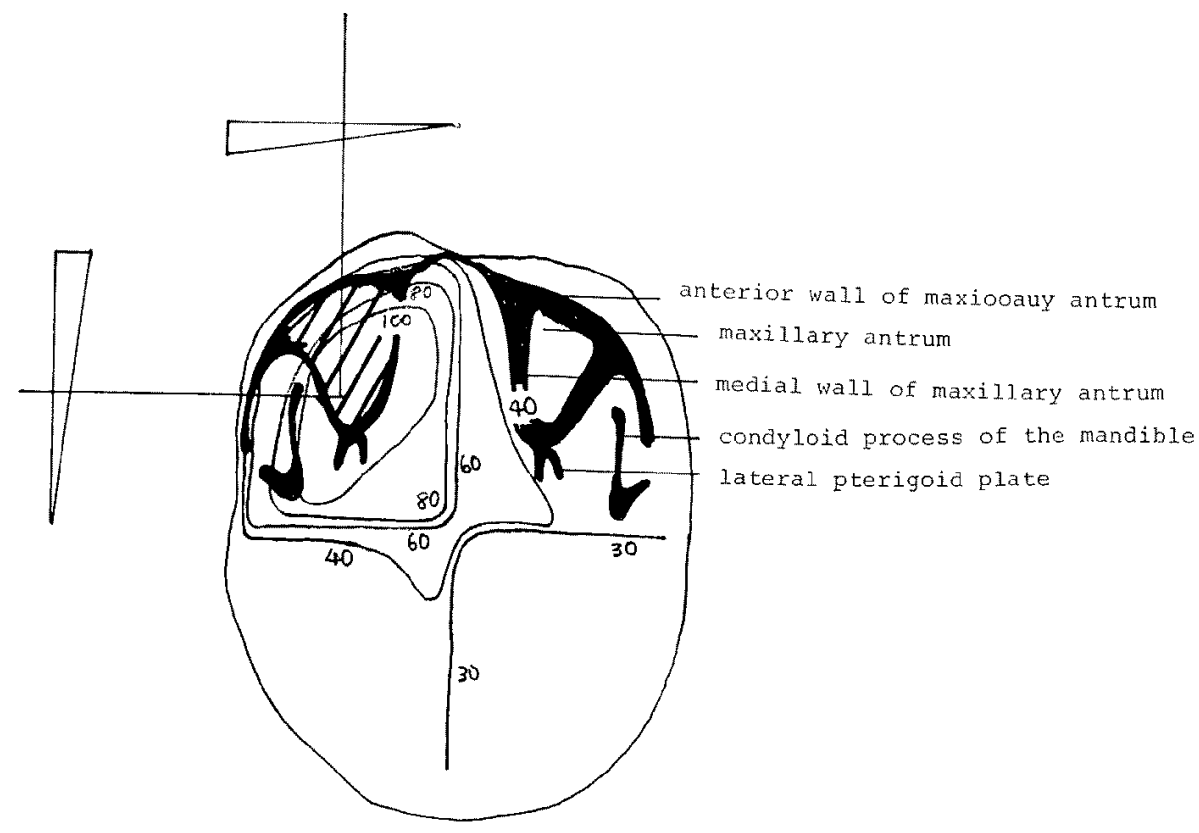

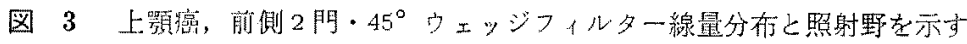

旬，すなわち最瑷の放射線照射㣪䄪 4 年 6 力月を経た胿 点で再度左顂部腫脹をみるようになり，悪性リンバ蕾の 再発を照念して昭和51年2月16日当科を訪れた。

B）第 2 回初診の病歴（14筬上なった）

現病歴抽よび経過:

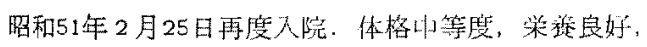

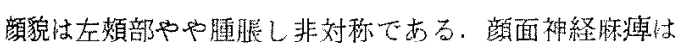
ない，左㚘部堙脹は耳前部を中心としてみられ，衏回の

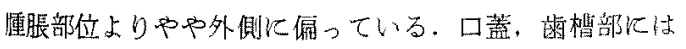
腫脤枋認められない。腫脤は境界不鮮明で弾性硬を呈す

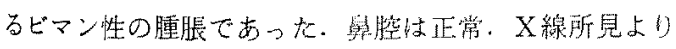

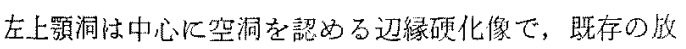

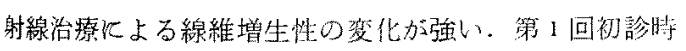

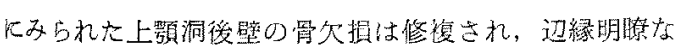
骨影像として投影されている。 又副受腔炎性桨化として とらえられた粘膜肥厚も改善されて，略正常な洞影像を

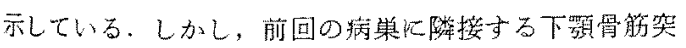

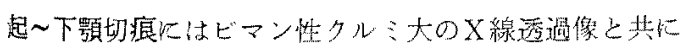

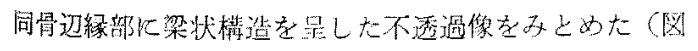

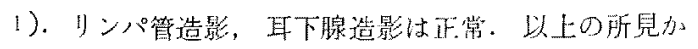

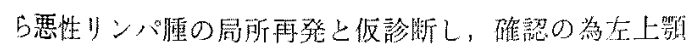

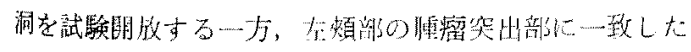

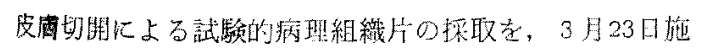

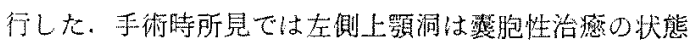

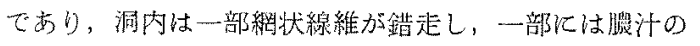

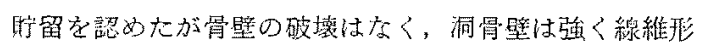
成により再貄されていて脾境の存在は認められなかっ

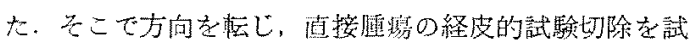

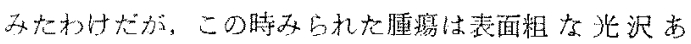

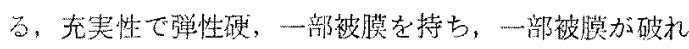
て周閒組蟣に浸潤した灰白色のヌルヌルした厘瘳であっ

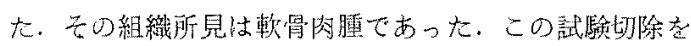

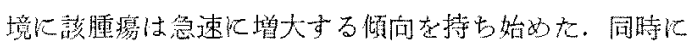

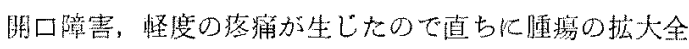

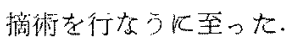

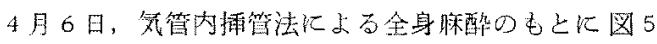

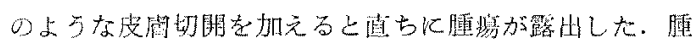

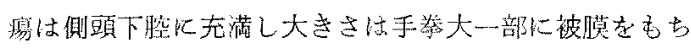

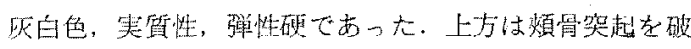

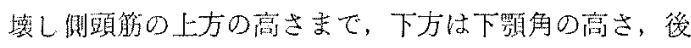

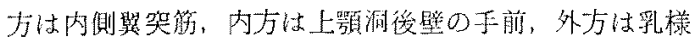

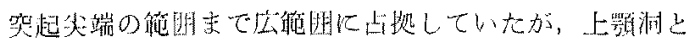

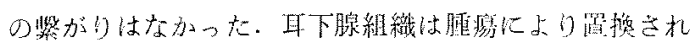

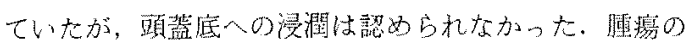

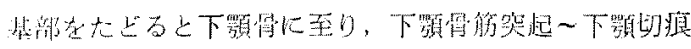

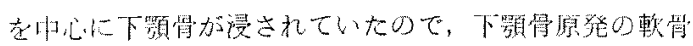


治療ならびに経過

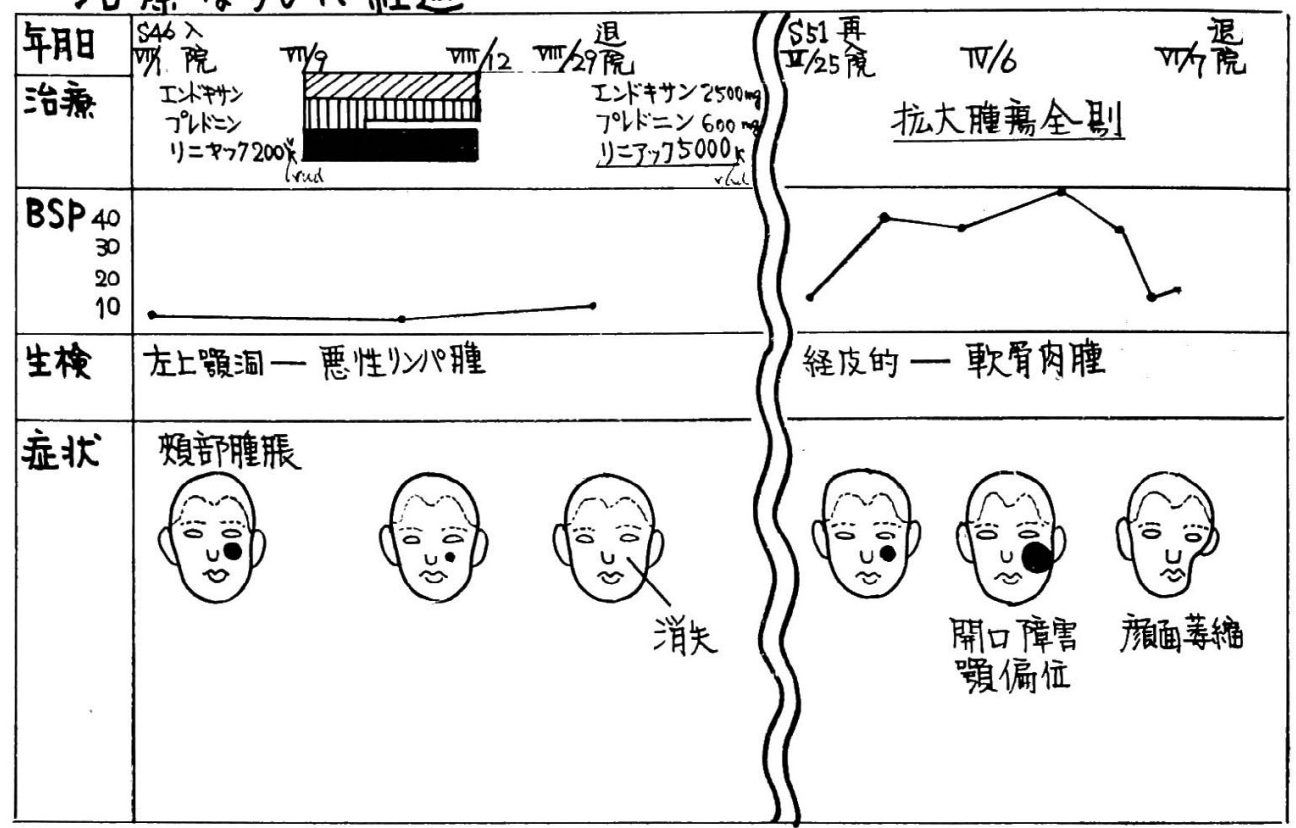

図 4

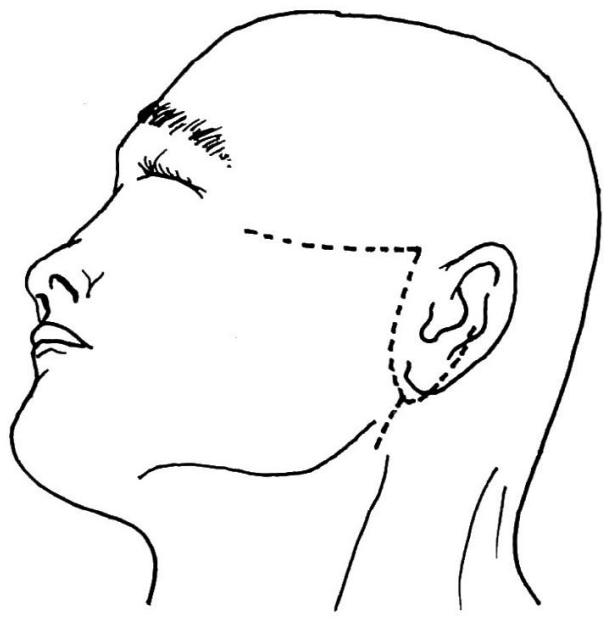

図 5

肉腫であると思われた(図 6). 腫瘍は煩骨弓, 耳下腺の 全部, 顔面神経, 下顎骨の一部, 側頭筋の下部, 咬筋, 煩 筋を含め一塊として摘出した. 摘出した腫瘁は灰白色, 硬いが脆弱な感じのもので割面でみると灰白色を呈して いる中存, 暗赤色の壊死状〜粘液化様部分を認め大. 顔 面神経は腫瘳の中心に位置していたので, 荃乳孔を出た

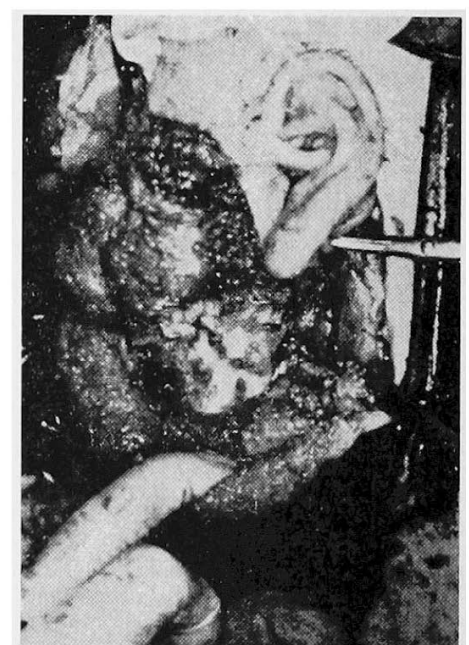

図 6 術中写真, 下顎切痕に一致した場所より 牌瘍が膨隆している。

外側にて切断した. 摘出後には巨大な死空の形成をみた ので残存側頭筋を有荃移殖して手術を終えた. 剔出した 腫瘍の組織検査でも軟骨肉腫と診断された. 完全搔爬後 の手術創はガーゼタンポンで圧迫しつつ健康な肉芽の増 生をはかったが, 移殖した側頭筋の一部は術後壊死飞陥 
入り瘦孔の形成をみた．そこで壊死組織の䅡極的除去を はかると瘦孔は閉鎖し, 6 月 7 日荌縮顔面の形成術を次 の課題として退院した. 現在術後半年の状態であるが再 発の徵しは認めない.しかし再発に関しては定期的な観 察が必要であると考えている。

組織学的所見:

図7では軟骨基質に近い myxomatous な matrix が 異常な増生をして扣り, その間に異形性の強い大小不 同,多形性で円形ないし楕円形, 紡鏵形を呈する軟骨細胞 が不規則に配例している.核は紡錘形ないし不整楕円形 でクロマチンに富み，二核性のものが認められる. 図8 は顔面神経の断面を示しているが, 神経の endoneurium は少なく萎縮性である， perineurium は層状構造をな し, 個々の細胞は薄い, 問質には軽度の炎症が認められ るが, 軟骨肉腫細胞の浸潤はない。

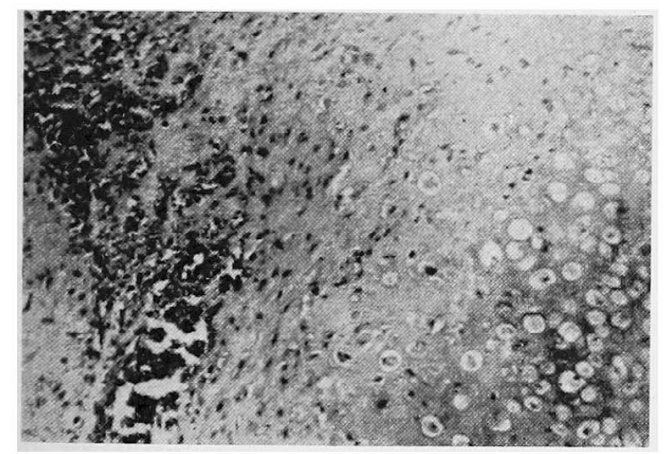

図 7

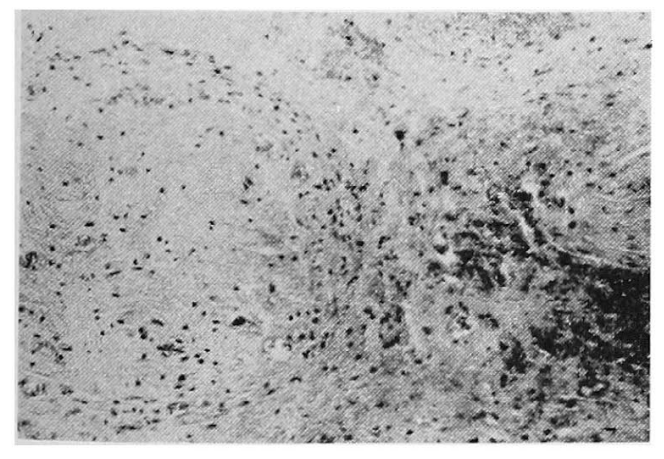

図 8

\section{III 考察}

\section{1. postradiation bone sarcoma に関すること}

放射線による発癌はかなり古くから知られて扣り，X 線発見 5 年後にはすでに皮膚への被嚗から拈こった最初 の皮癌が報告されている，その後放射線によって他の
種の癌が誘発されることが徐々に認められるようになっ

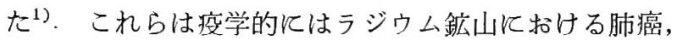
ラジゥム文字板筆工の骨腫瘍および白血病, 放射線治療 後の皮症癌, 甲状腺癌, 咽頭癌として知られている7).

放射線治療後に生じる骨肉腫は1922年に, Beck が報 告した関節結核に対して放射線治療を施した後に生じた 3 例の症例報告をもって噙矢とするようである. その後 同様の報告が続いたが，元来，大線量放射線被曝により 骨癌が生じることは稀な現象であり，それまでの経験で は概して放射線によって起された癌の型は明確なもので はなかった. そこで1948年 Cahan 等 ${ }^{3)}$ は postradiation sarcoma という名称で呼ばれている一連の症候群の定 義つけを行ない，次のような 4 条件を設置した。すなわ ち発癌の基盤となる骨組織は常に病理組織学的扣よびX 線学的に良性の性格を帯びたもので, 続発した骨肉腫は 以前受けた放射線治療の照射部内に限られ，発癌に至る まで比較的長い無症状の潜伏期を経過し, 病理組織学的 に肉腫を証明できること，であるとした(図 9). この基 準は, Cahan 以降の postradiation bone sarcoma の報 告者に正当な基準として採択されてきた感がある.

1. 病理組織学的およびX線学的に良性の骨組織を 基盤沉すること

2. 続発した肉腫は以前うけた放射線治療の照射野 内に限られること

3. 比較的長い潜伏期を有すること

4. 病理組織学的に肉腫を証明できること

図 9 Postradiation bone sarcoma の 4 条件

そこで従来の postradiation bone sarcoma の報告を 通覧すると，この種の報告は頭蓋骨に少なく稫幹骨，四 肢骨に片奇る傾向にある. 特に, 大腿骨の下端, 䀴骨の 上端が好発部位とされている．何故に顔面頭蓋に少ない かは不明だが，この種の臨床報告では，Cruz の聏平上皮癌にラジウム針と X線治療を行ない，13年後 に上顎骨骨肉腫の発生をみた例, Wolf $\mathrm{e}^{6)}$ 等は, 外鼻の 皮症症の放射線治療後に生じた鼻骨の骨原性肉腫の2 例, Jones ${ }^{5)}$ は, 下顎の actinomycosis に対し25力月間 に 2 度飞亘り総量 6700 r のレントゲン治療を加えた結 果, 9 年後飞 ascending mandidular ramus 飞骨原性 肉腫の形成をみた例を, 又前述の, $\mathrm{Canan}^{3)}$ は, 下顎骨 の骨形成性線維腫に 13 年間で 2 度に亘る総量 4500 r の 照射後に生じた 1 例, 更に上顎洞炎, 節骨洞の retinoblastoma の放射線治療で発生した 2 例，計 3 例の骨原性 
肉茞例克報告している。これるは全て postradiation osteogenic sarcoma 報じたものであるが，軟筒肉朠

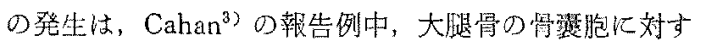
る戊射線治潦俊，(1550r)，17年目化生じた1例が为b れる.

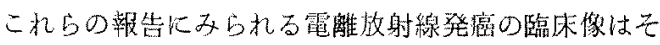
れそれの放射線の生物学的作用, 組織自体の生活状態な

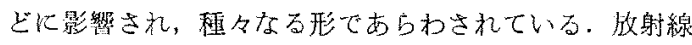
の作用受けた原骨組織は，正常の骨組織力口(結核性) 閏節炎, 巨細胞腄, fibrous dysplasia と多棌であり，

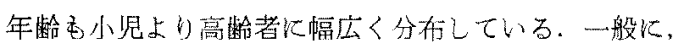

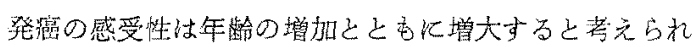

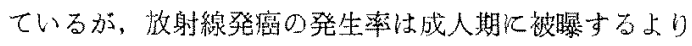
6、幼览期や小見期に被曝した万が影響を受けやすい上

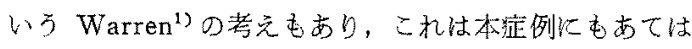
まるようである。

癌発生摔一線量関係山，まだ定まった意見をみない が，一般に骨組織の放射線の感受性は釱く，霄組織の倠 化はかなり大量照射しないとあらわれず，また非常飞遲 くあらわれ，加学加回復しないといかれるので，一般

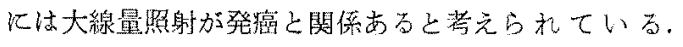

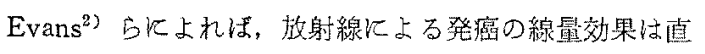

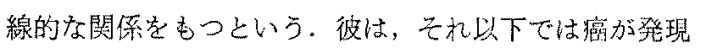
しないという“,実用閾値”の概念を導入した.
この直線性の最も良い証掞は，日本の原爆生存者の白 䢐病沉ついての情報と思われて招り，現在この直線関係

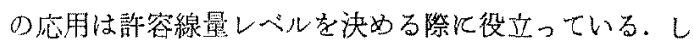
かし，この作説が必ずしも当を得ないことは，すべての 組織への一定線量の照射によって，版射楾悪性腫瘦が同 し比率で增加しないこと加ら指撴できる。

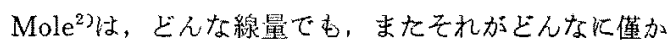
であっても瘐を机こすチャン人が必ずあると, 小線量照 射ての発诲の可能性を説いている。

ところで，文献上で発獾一線䁷関係を聇例により示す

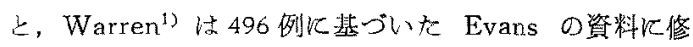

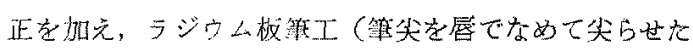

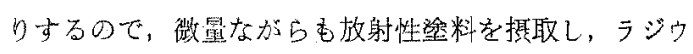

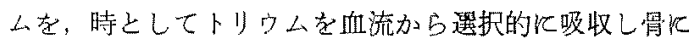

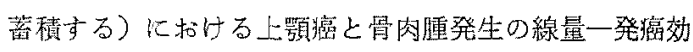
果を示している(図10)。これによれば，線量と発癌頻 度の間に一定の閔倸志認めること哇できないが，全体上 してみれば, 線㫪が多くなれば瘦の発生率は高くなるよ

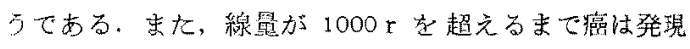

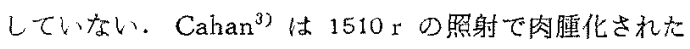
fibrous dysplasia と骨㢣胞に1550 rを扣えただりで2 年後江軟骨肉腫化した 2 例を除けは，発澺に要する最小

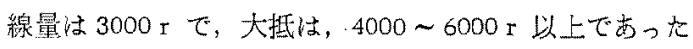

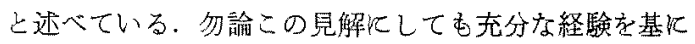

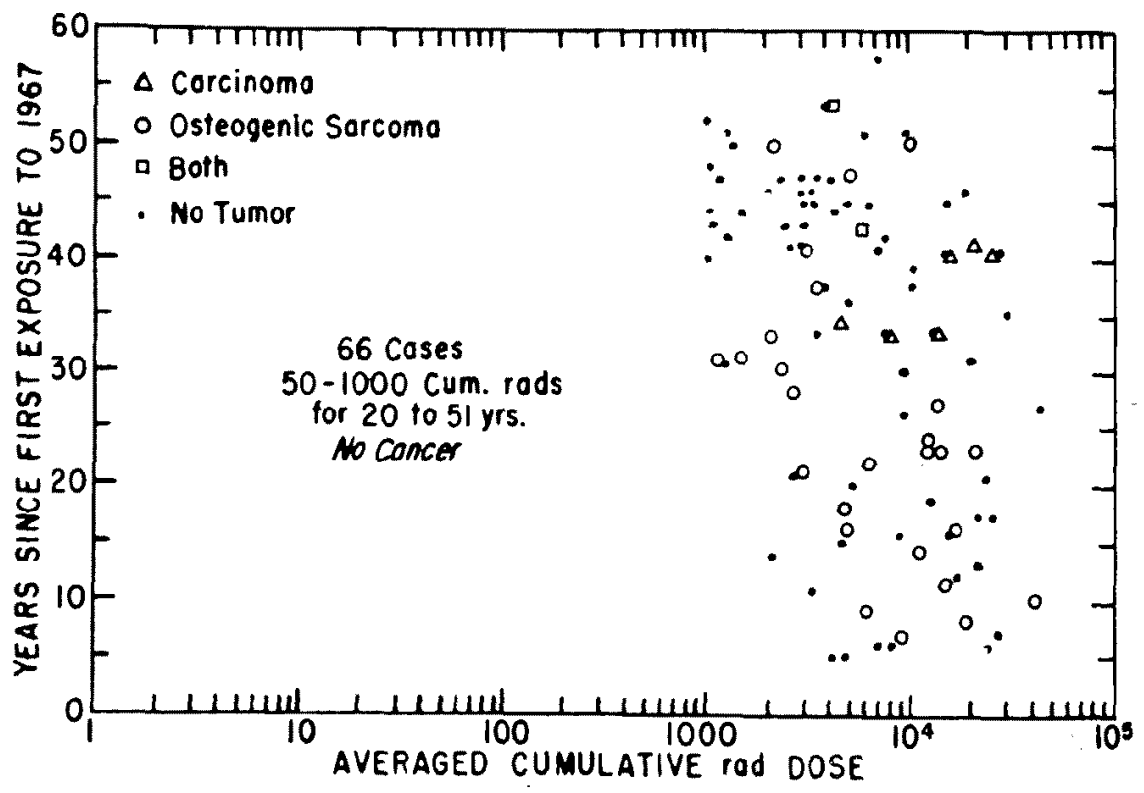

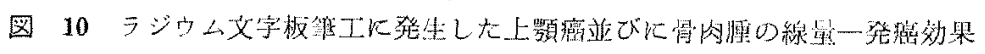


しているものではなく，また照射部に资定があり，嗹猩 自体が感染していれ放射線の感受性に变動が起き得る かけである、同様に，与えられた線量が $4000 \mathrm{r}$ 上か $6000 \mathrm{r}$ とかいっても，幾日間で照射されたかが示されなけれ

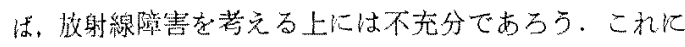
閏して，Cruz ${ }^{4}$ Ф症例は $1000 \mathrm{r} \sim 5289 \mathrm{r}$ ，照射期間性 1 力月より9年炕亘り，Jones ${ }^{5}$ 结最低 20 年上り垠高 19 年 て発福した例を報告している。

潜代期は放射楾照射を終了した侍点上り，組織的に独 兑証明するまでの期間在さすが，余り長年月に亘り繰り 返し照射し続けた例はどの时点での霓崔放射線が発癌に

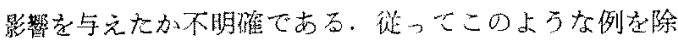
外した Jones ${ }^{53}$ の39例で洁，潜伏期仗 3 年上り22年飞亘

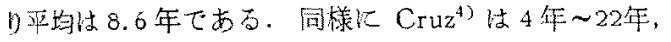
$\mathrm{Cahan}^{33}$ は 5 年 22 年, 平均 11 年と述べている。わ机 われの症例は 34 日間で $5000 \mathrm{r}$ 上諸般の報告に比較する と小線量照射の部頪に入いり，葄伏期は 4 年半上短加い が，しかし小線量照射て短期間の潜忋期であったとして も，放射線を浴びる原骨組織の生活状態沉より放射線の 感受性、放射線儿上る影響上りの回復に差があるわけだ

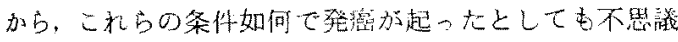
てはない，現に5000 $\mathrm{r}$ 照射滛にみられた該部の著しい

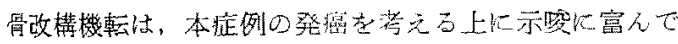
いるように思えるのである。

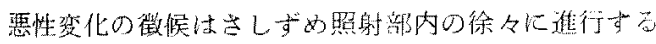
疼痛と睡脤であるう。本症例では初期には無症状であり，

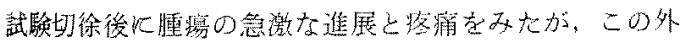

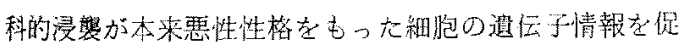

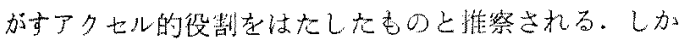

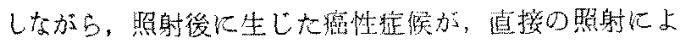
り峞起される骨罱死，骨䯣资之区别し得るものであ万う か、特炕下顆骨は力ルシウムが祭富であり，血流がさし

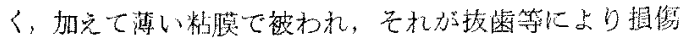

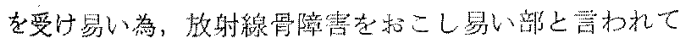

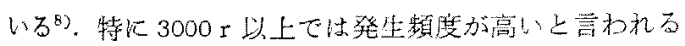
が，Jones ${ }^{52}$ に上狆ば，放射線骨炎上放射線発蒖之の鑑

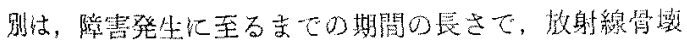
死惊管閉塞汇上り起り易いので，照射後引き続き世い ぜい6力月上り1年, 長くて5年の間にみられるのに比

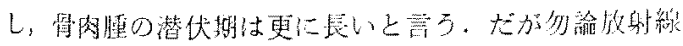

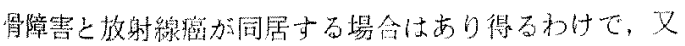

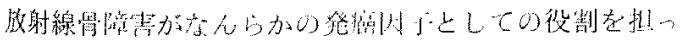
ていることも想像される。.Sabans ${ }^{93}$ によ机标，17例中
15例の postradiation bone sarcoma K性腺機能減退,

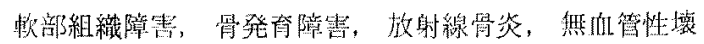
死，病的骨折汃伴なっていたと赤皆している。

ところで饭射線により誘発される胃肉腫上，他の要团

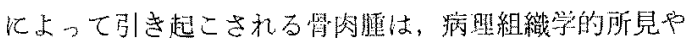

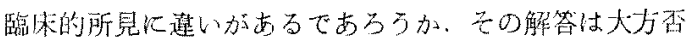

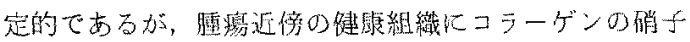
化，買常な線維細胞，血管の摃傷などり突化が認められ

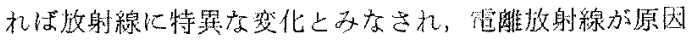
として推測できるという穼見もある1

放射線炕上る発癌の機構老説明する圷めに古来，実䮖 的誘発癌の研究が数多くなされてきたが，二れは細胞代

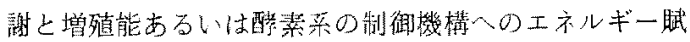

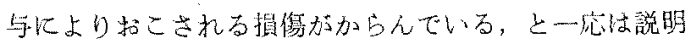

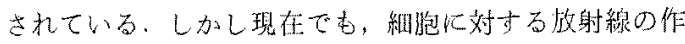

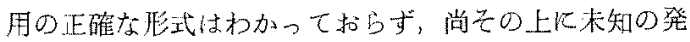

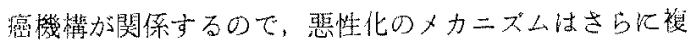
雑であるうと予想される。

以上述以てきた放射線発揊は，放射線治撩と密接な関

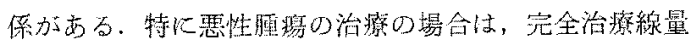

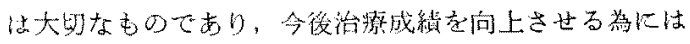

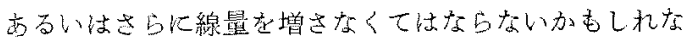

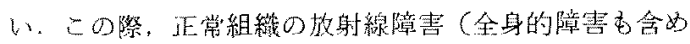
る）に対して，常に多くの注熱を払い，この障㕩を银小 腿に上どめるべく努力して初めて完全治療を行ないうる

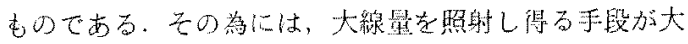

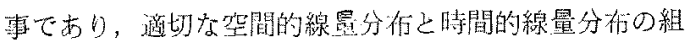

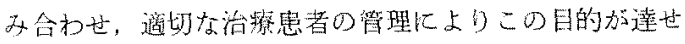

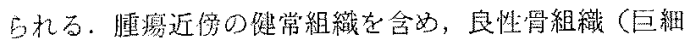
胞腷，骨筫線維症ら含む)飞照射する場合には線量の配

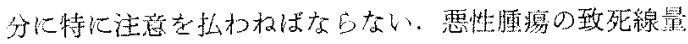

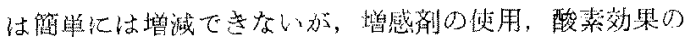
利用，さらに将来は重粒于線の活用などにより致死線㻎

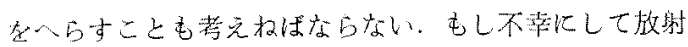

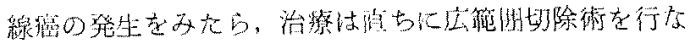
うべきであるう。

\section{2. 額軟骨肉腫に関すること}

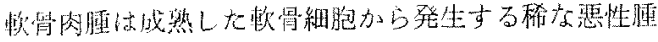

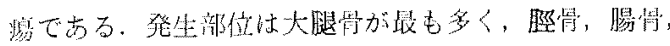

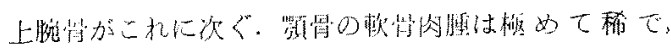

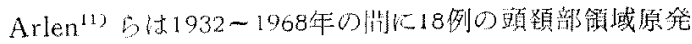

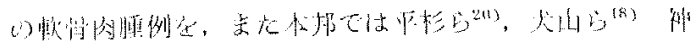

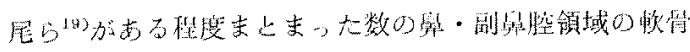




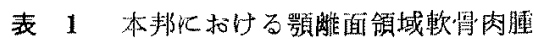

\begin{tabular}{|c|c|c|c|c|c|c|c|c|c|c|c|}
\hline 症例 & 㫰菣者・年 & 年代 & 年齢 & 性 & 部 & 位 & 初 回 治 䅫 & 再発 & 塥 発 時 液 療 & 子 & 後 \\
\hline 1 & 小 林(静) & ' 17 & 40 & 우 & 學中 & 隔 & & & & & \\
\hline 2 & 西 村 & 33 & 42 & $\delta$ & 上 & 颚 & 上 覆 全 摘 & + & & & \\
\hline 3 & 正 木 & '38 & & & & 顎 & & & & & \\
\hline 4 & 大 浦 & 41 & 51 & $q$ & 下 & 顎 & 下 額 部 奵 & + & 下 顎 全 摘 & & \\
\hline 5 & 横 田 & $' 42$ & 31 & 3 & 下 & 旗 & X線，下蛽部切 & & & 良 & 杍 \\
\hline 6 & 小林 & ' 43 & 32 & ㅇ & 下 & 嵱 & 下顎部切， $\mathrm{X}$ 楾 & & & 良 & 好 \\
\hline 7 & 小 $川 11$ & '52 & 25 & $\delta$ & 上 & 䫟 & 上顎 全 摘 & & & & \\
\hline 8 & 和々本 & '53 & 50 & 우 & 上 & 顎 & 上頡 部切 & + & 腄演摘 出 & 死 & $\leftarrow$ \\
\hline 9 & 加 藤 & $' 55$ & 60 & $q$ & 上 & 顎 & デンケル & + & Rn. X線 & 不 & 良 \\
\hline 10 & 地 引 & '58 & 43 & $q$ & 上 & 䫂 & 腫 癔 墒 出 & + & & & \\
\hline 11 & 小 林(春) & '60 & & $q$ & 上 & 顎 & & & & & \\
\hline 12 & $"$ & $"$ & & $q$ & & 腔 & & & & & \\
\hline 13 & 乗 金 & $' 61$ & & & 嶨中 & & 腫晟摘江 & & & & \\
\hline 14 & 内 蒋 & $' 62$ & 3 & $\hat{b}$ & 上 & 顎 & $テ ゙ ン ケ ル$ & + & 揰瘍摘出, $\mathrm{X}$ 線 & 死 & 亡 \\
\hline 15 & 河辺 & $' 62$ & 27 & $\delta$ & 上 & 瀬 & デンケル, Co, X線 & & & 死 & $亡$ \\
\hline 16 & 柳 䧉予 & $' 64$ & & & & 顎 & & & & 死 & 亡 \\
\hline 17 & 滝 川 & '65 & 24 & 3 & 上 & 顎 & 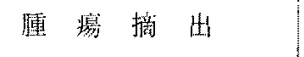 & + & 腫 揚 摘 出 & & \\
\hline 18 & 住 藤 & '65 & 21 & $q$ & 上 & 頍 & Ra. X 線 & + & Ra、X線，上顎全摘 & 死 & 亡 \\
\hline 19 & 山㥓 & '66 & 53 & $\hat{s}$ & & 颉頁 & Co. Eadoxan. 上颚全摘 & & 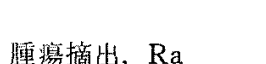 & 死 & 亡 \\
\hline 20 & 武 内 & '66 & 46 & 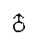 & 齄中 & & Ra. & + & & 泉 & 杍 \\
\hline 21 & $\equiv \#$ & '68 & 53 & $q$ & 下 & 頕 & 下 颉 部 切 & + & & 死 & 亡 \\
\hline 22 & 神 尾 & '69 & 75 & $q$ & 上 & 擷 & 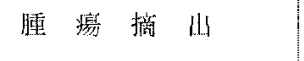 & + & 㕰瘦摘出，Co & 死 & 亡 \\
\hline 23 & 米田 & 70 & 45 & $q$ & 上 & 谔 & 腫 演 摘 出 & + & 腫缸摘出 & 良 & 好 \\
\hline 24 & 佐々木 & 70 & 46 & 3 & 下 & 顎 & 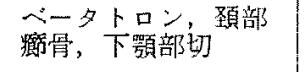 & + & & & \\
\hline 25 & 平松 & $' 71$ & 59 & $q$ & $上$ & 顎 & 上 旗 全 摘 & & & 良 & 好 \\
\hline 26 & 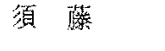 & $' 72$ & 42 & $\delta$ & 下 & 顎 & 下顎部划，放治 & & & 良 & 好 \\
\hline 27 & $"$ & $"$ & 41 & $\beta$ & 下 & 顎 & 下 顎 部 叮 & & & 良 & 好 \\
\hline 28 & 古明 & $' 73$ & & & 下 & 䕱 & 下 顎 部 切 & & & & \\
\hline 29 & 加 藤 & $' 74$ & & & & & & & & & \\
\hline 30 & $" \prime$ & $"$ & & & & & & & & & \\
\hline 31 & 永 壮 & '74 & 30 & ? & F & 愕 & 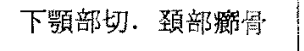 & & & & \\
\hline 32 & 白 憣 & 76 & 14 & 9 & 下 & 吅 & 下 敫 部 切 & - & & 这 & 好 \\
\hline
\end{tabular}




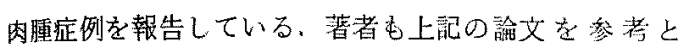

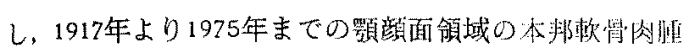

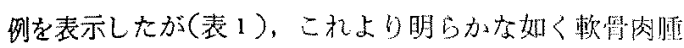

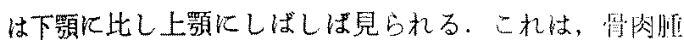
が下顎に多いのと対照的である。性则では男性にやや夕 くみられ，普通20〜30藏以上に多発するようであるが，

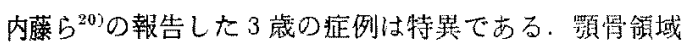
での好発部位は，下颚では後方部，特に筋突起と関節突

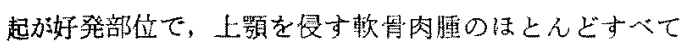
は，前上顎部に発生する。

軟骨肉腫は軟骨の石灭化，胃形成あるいは此液腄様变 化などから，osteochondorosarcoma, chondoroosteo sarcoma, chondoromyxosarcoma, myxochondoro sarcoma などと呼はれ22)，盷眼的には圧白色透明でヌ ルヌルしている，硬度は石灰化の程度により様々だが，

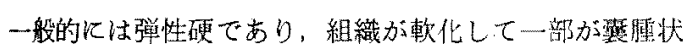
となり，粘液を䝪留すれば波動性に能れることになるの で注意を要する。本症例の如く覀性度の強いものでは一 部填死状を呈することもある。㳄骨肉脏の分類は発生母 地の部位と性格により，骨の内部加ら発生する中心性 (central) 軟骨肉腫と，骨の表面加占発生す吕末悄性

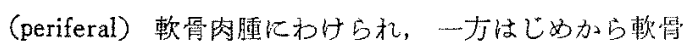

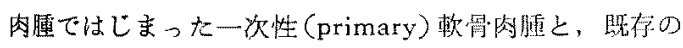
良性の軟骨腫瘍 enchondroma, cartilaginous exostosis などから発生した二次性（secondary）颙骨肉腫と炕分 類されている：この分類に本症例照らし考える上，わ

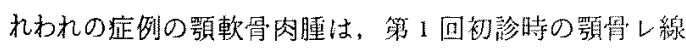
写真では，睡瑒発生部位は正常常影を示しているとこる 加，骨膜由来のものてあり，留の表面炕発生した梢 性軟骨肉腫であると思われた。

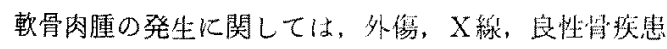
と3つの大きな因子が考えられる。このう古本症例心， 放射線江より誘発された一次性軟骨肉臛てある可能性が ある(前述)，統計的飞は大部分が一次性て，二次性軟监 肉㾖の報告では，約23年間の長い経過で靯骨腫より軟臂 肉腫になった末田ら ${ }^{23}$ の例， 7 年閒の资症刺激が吹骨腫

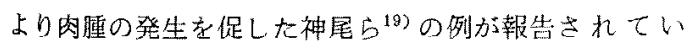

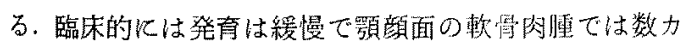

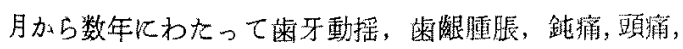

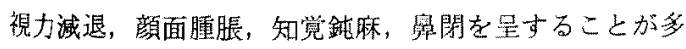
い.したがって2〜3年老経て来院するすのが少なくな

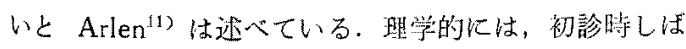

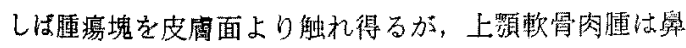

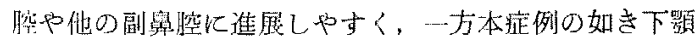

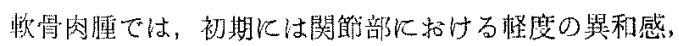

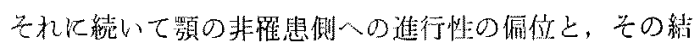

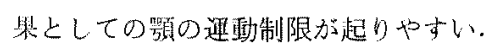

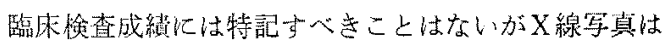

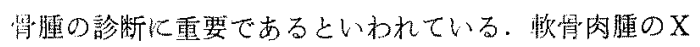

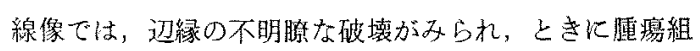
織加石灰化すると玟点状のX線不透過像を伴なう。と

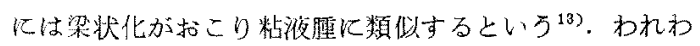

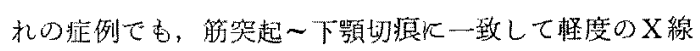
不透過像，梁状化がるられたが，さらに克明な描写を期 待する場合には回転断層などの特殊撮影が用いられる心゙ きであらら。

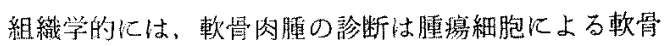
の班成が立証される時につけられる。乙して睡慯細胞で ある軟骨細胞を覀性腫嗐細胞であるとみなす最も重要な 判定㟟準㤬，多核細胞と核の大きさの增大であり，個々 の細胞の大きさに著しい变化があって異常なタロマチン 模様を呈するこ上である。この点が軟学㣫との鑑别上し

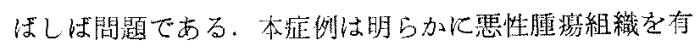

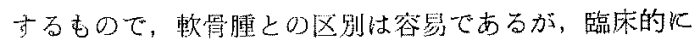

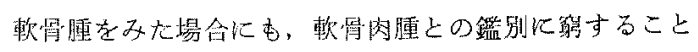

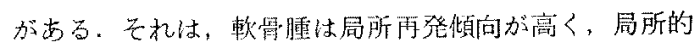

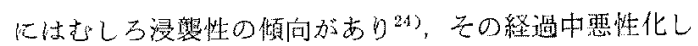
ていくのもあるからて，靯骨腫は病理組織学的には良性

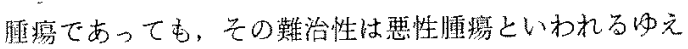
んである。この軟骨堙の瑟性度は時期と場所により異な

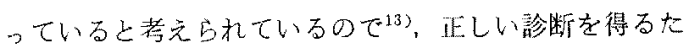
わには，まず武験切除化当り挫隇が少なく，ある程度の

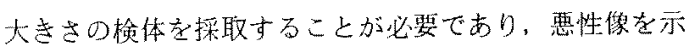

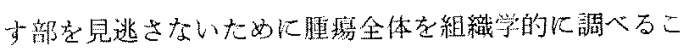
とが重要であると思われる．更に患者を follow-upしな がら鮥断能力を自分で培うことも必要である。

軟曷肉隀と骨闪腫を区别することもしばしば因蜼であ

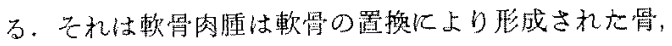
すなわち腫激そのものから壁牛されたものでない骨を含 さことがあり，素た骨肉腫であ杴骨形成が出現したりす

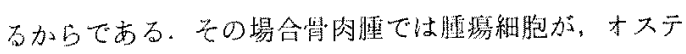
オイド(類骨一まだ石网の沈着していない細い骨組織） を作るのが最大の特徴であるので，骨肉腫でと元軟瓦

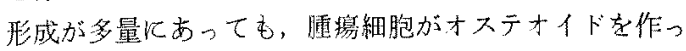

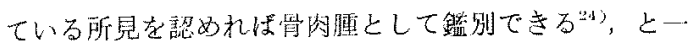

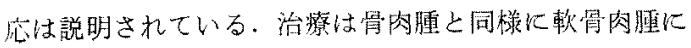


刘して古，放射線，抗㟫療法の效果は薄いのて，初回手

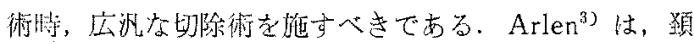

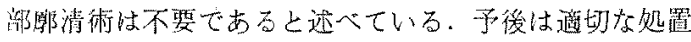
がなされる限り，骨肉腫よりやや良效であるが，血行性

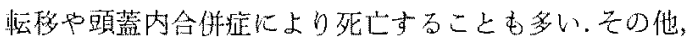
大出血感染症，全身衰弱などが間接死の原内となる。

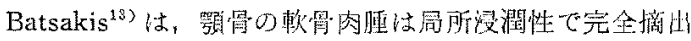

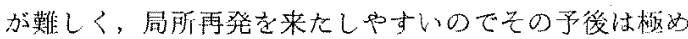

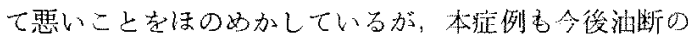

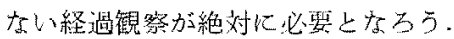

\section{おわりに}

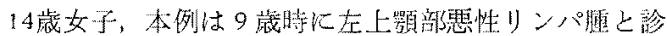
断され，リニヤック $5000 \mathrm{rad}$ 照射，伊世て抗癌剂療法

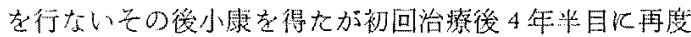

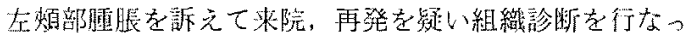

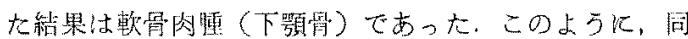

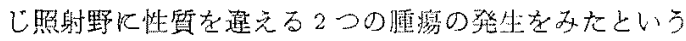
ことは，後発の霾嗄は先行した放射線治燎が引き金とな $\Rightarrow$ て綵発された postradiation bone sarcoma の可能性 がある。そこで，管を基然とする炇射線による発癌につ

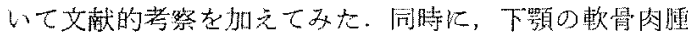

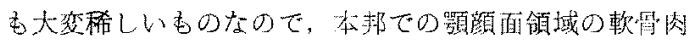
臛32例について文献的に芳祭した。

\section{主要文献}

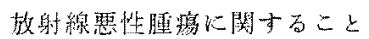

1) Shields Warren.: Bulletin of the New York Academy of Medicine, 46; 131-147, 1970.

2) R.H. Molw.: Ionizing radiation as a carcinogen: Practical question and academic pursuit. British Jiurnal of Radiology, 48; 157-169, 1975.

3) W.G. Cahan, et al.: Sarcoma arising in irradiated bone. Cancer, 1; 3-29, 1975.

4) M. Crus, et al:: Postradiation bone sarcoma. Cancr, 10; 72-88, 1975.

5) A. Jones, et al.: Irradiation Sarcoma. The British Journal of Radiology, 26: 273-284, 1953.

6) J.J. Wolfe, et al.: Postirradiation osteogenic sarcoma of the nasal bone. Cancer, $2 ; 438-446$, 1949.

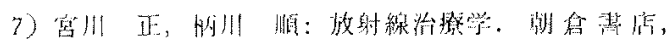
1975 . (11/450)

8) Kobinson, et al.. Surgical management of radio osteonecrosis of the head and neck. Symposium on cancer of the head and neck (Vol, 2). C. V. Mosby 1968.

9) A. O. Sabanas, et al: Postradiation scoma of bone. Cancer, 9; 528-542, 1956.

10) G.H. Hatcher.: Developement of salcoma in bone subjected to roentgen or radium irradiatio. J. Bone \& Joint Surg, 27; 179-195, 1945.

欸骨肉腄に䦥すること

11) Arlen, M., et al.: Chondroarcoma of the head and neck. Am. J. Surg, 120; 456-460, 1970.

12) Cnandhry, A.P., et al.: Chondrogenic tumors of the jaws. Am. J. Surg. 22; 403-411, 1961.

13) Botsakis, J.G.: Tumors of the head and neck, clinical and pathological considerations. The witliand, coilkons company, Baltimore; 291-293. 1974 .

14) Thoma, K.H.: Oral surgery, volume two. The C. V. Mosby Company, saint louis. 1969.

15) Kragh, L. V., et al.: Cartilagenous tumors of the jaws and facial region. Am. J. Surg. 99; 852-956, 1960.

10) Miles, A.E.W.: Chondrosarcoma of the maxilla. Br. Dent. J. 88; 257-269, 19560.

17) Pindborg, J.J.: The incidence rate of jaw sar. comain Denmark. 1943 to 1953. Oral Surg. $1961 ; 14 ; 276-279$.

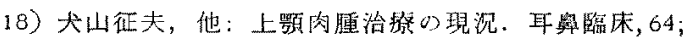
403-424, 1971。(昭46)

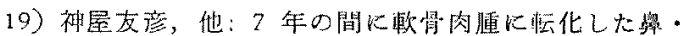

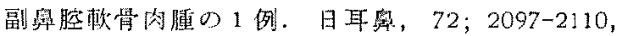
(昭44)

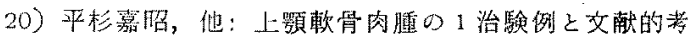
察. 65；1169-1175，1972。(凅47)

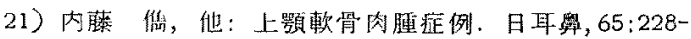
230, 1962. (爿37)

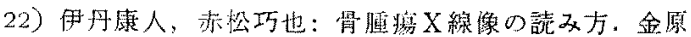
专此, 1976、（招51）

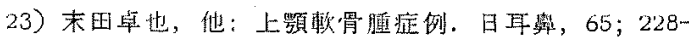
230, 1962. (吸32)

24) 增田 游, 他: 上影軟骨腫の1例, 耳喉, 45; 503507，1973.（昭48）

25）金于 仁：罚肉腫と㜞骨肉腄. 日医報，2714；4345,1976 . (昭51)

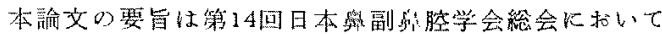
口演した。

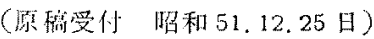

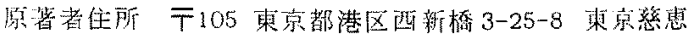

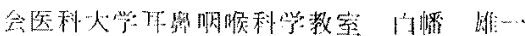

